\title{
Effect of Sulphonylurea Derivatives and Short Chain Fatty Acids on Expression of Incretins Hormone in living Animal Cells Emad Gad $^{1 *}$, Atef Gouda ${ }^{2}$, Mohamed A. Ghany ${ }^{1}$, and Nermin Raafat ${ }^{2}$
}

\author{
${ }^{1}$ Chemistry Department, Faculty of Science, Suez Canal University, Egypt \\ ${ }^{2}$ Medical Biochemistry and Molecular Biology Department, Faculty of Medicine, Zagazig University, Egypt
}

\begin{abstract}
Dietary fibres are a type of carbohydrates that are found in plant-based foods. They are not absorbed or digested by the body but play an important role in maintaining good health. Short-chain fatty acids (SCFAs), primarily acetate, propionate, and butyrate, are metabolites formed by gut microbiota from these complex dietary carbohydrates. The formed acids have a role in the secretion of hormones such as glucagon-like peptide-1(GLP-1) and glucose-dependent insulin tropic polypeptide (GIP) that help the body to control diabetes. Diabetes mellitus is a chronic disease that occurs when the pancreas fails to produce enough insulin, or when the body cannot use it effectively. The hormones GLP-1 and GIP, which secreted after a meal, like other enteroendocrine hormones help to orchestrate the body's response to the availability of newly absorbable nutrients and are noteworthy, stimulate postprandial insulin secretion. This study clarifies the effects and the roles of organic compounds such as Short Chain Fatty Acids (SCFAs) and sulphonylurea derivatives on body glucose homeostasis and clarifies the effects of both SCFAs and sulphonylurea on incretin expression by investigating the expression of GLP-1 and GIP hormones in tissues and blood samples. Keywords: Microbiota, Enteroendocrine hormones, Sulphonylurea derivatives, glucagon-like peptide1(GLP-1).
\end{abstract}

\section{INTRODUCTION}

Diabetes Mellitus is becoming the fast prevalence disease, approaching epidemic ratio, all over the world. The International Diabetes Federation (IDF) listed Egypt among the world top 10 countries in the number of patients with diabetes. It is expected that the number of patients with diabetes in the Middle East and North Africa (MENA) region to grow by $96 \%$ from year 2013 to 2035 or from 34.6 million to 67.9 million. In Egypt, the prevalence of diabetes is around $15.56 \%$ among adults between 20 and 79 years of age, with an annual death of 86,478 related to diabetes. In 2013, the IDF estimated that 7.5 million individuals have diabetes and around 2.2 million have pre-diabetes in Egypt. Furthermore, reports indicate that $43 \%$ of patients with diabetes and most patients with pre-diabetes in Egypt are likely undiagnosed. It is alarming that diabetes prevalence in Egypt has increased rapidly within a relatively short period from approximately 4.4 million in 2007 to 7.5 million in 2013. It is expected this number will jump up to 13.1 million by 2035 (IDF, 2013). By micro biota in the colon and the distal small intestine Short Chain Fatty Acids (SCFAs) are produced from dietary fiber, resistant starch and other low-digestible polysaccharides in a fermentation process (Kaual et al ., 2011).

There are very important role of SCFAs in regulation of gut hormones. Endocrine cells in the gastrointestinal tract (named enteroendocrine cells) secrete a range of hormones that regulate glucose homeostasis, gut motility, epithelial proliferation, appetite and adiposity. Two gut peptides, glucose dependent insulin tropic polypeptide (GIP, formerly known as gastric inhibitory polypeptide) and glucagon like peptide1 (GLP-1), are widely recognized for their role as incretions, and under lie the augmentation of insulin secretion that is observed when glucose is administered orally rather effect has been estimated to account for $50-70 \%$ of total postprandial insulin secretion (Holst, 2007). Although it primarily considered as a response to oral glucose, it may also play a physiological role following lipid ingestion (Lindgren et al., 2011).

Sulphonylureas derivatives are used for the treatment of type 2 diabetes. Glimepiride is one of the third generation sulphonylurea drug having a poor aqueous solubility, slow dissolution rate and low elimination halflife (2-3hrs) (Davis, 2004). Glimepiride has a number of advantages over other members of sulph-onylurea, currently used as lower dosages, fast onset of action and lower C-peptide level of insulin, this is because of less secretion of insulin and more pron-ounced extra pancreatic effects (Ammar et al., 2006). The acting mechanism of glimepiride is binding to the specific site on pancreatic $\beta$-cells and blocks the ATP-Dependent potassium channels to stimulate the insulin release. Due to the short elimination half-life, frequent dosing is required which leads to the adverse effects such as headache and gastrointestinal disorders (Mrillerg et al., 1994).Therefore, this study was carried out to investigate the effect of sulphonylurea derive-atives and SCFAs on the expression of incretions hormone.

\section{MATERIALS AND METHOD}

This study was carried out in Chemistry Department, Faculty of Science Suez Canal University and Scientific \& medical Research Center (Molecular Biology Unit). Zagazig University. This study was done from November 2017 until March 2018.

\section{Experimental animals}

Fifty young adult healthy male albino rats, weighed between 150 and $200 \mathrm{~g}$, were used in this study. The rats obtained from the El-Nile pharmaceutical and Chemical Industries Company, Cairo, Egypt. They 
were maintained on standard pellet diet and tap water. The animals were housed in suitable cages in conditioned atmosphere $\left(22-25 \pm 2^{\circ} \mathrm{C}\right)$. The experiment was accomplished in accordance to the internationally accepted standard ethical guidelines for laboratory animal use.

\section{Dosages preparation for treatment}

Four different treatments were carried out in which two different concentrations of either SCFAs or glimepiride were prepared. For SCFAs, a mixture of $500 \mathrm{ml}$ of propionic acid $(35 \mathrm{mmol} / \mathrm{l})$ and $500 \mathrm{ml}$ of butyric acid $(20 \mathrm{mmol} / \mathrm{l})$ was used and named A. However, the second concentration, B, of SCFAs was a mixture of $500 \mathrm{ml}$ of propionic acid and $500 \mathrm{ml}$ of butyric acid with concentration of $50 \mathrm{mmol}$ and $30 \mathrm{mmol} / 1$, respectively. For glimepiride, two different solutions were prepared in which 0.150 and $0.075 \mathrm{mg}$ of glimepiride were separately dissolved in $10 \mathrm{ml}$ sterile distilled water and left overnight.

The preparation of glimepiride was carried out by melting the desired amount of glimepiride (mg) in 10 $\mathrm{ml}$ distill water and left overnight. Dosage was prepared for 21 days by melting $15.75 \mathrm{mg}$ of glimepiride in $210 \mathrm{ml}$ of distill water.

\section{The Experimental design}

Rats were randomly divided into 5 groups with 10 rats each. The groups were as follow: Group1, no dose was given (control group). Group2, in this group $3 \mathrm{ml}$ ( $1.5 \mathrm{ml}$ every 12 hours) were injected daily, for each rat, with stock solution A that prepared from a mixture of $500 \mathrm{ml}$ of propionic acid $(35 \mathrm{mmol} / \mathrm{l})$ and $500 \mathrm{ml}$ of butyric acid (20mmol/1). Group3, the rats were separately injected daily with $3 \mathrm{ml}(1.5 \mathrm{ml}$ every 12 hours) of higher concentration of SCFAs. The injected solution contained propionic $(50 \mathrm{mmol} / \mathrm{l})$ and butyric acids $(30 \mathrm{mmol} / \mathrm{l})$. Group 4 , in this group each rat was injected with $1 \mathrm{ml}$ per day with stock solution prepared from $0.150 \mathrm{mg}$ of glimepiride. Group5, each rat in this group was injected separately with $1 \mathrm{ml}$, per day, of stock solution contained $0.075 \mathrm{mg}$ of glimepiride.

All groups were given their own dose for three weeks and kept under healthy housed mentioned conditions. The rats were slaughtered at the end of the examined period. The whole experiment was carried out in animal house at Faculty of Medicine, Zagazig University.

\section{GLP-1and GIP gene expression detection protocol}

All members of this study were subjected to relative quantitative expression of GLP-1and GIP in peripheral blood and intestinal tissues by Real-time RT-PCR technique. The Analyzes were performed using Strata gene MX 3005p Real Time.This method involved extraction of mRNA, reverse transcription to cDNA then selective amplification via Real-time PCR system using DNA fluorescent dyes.

\section{Sampling technique}

(A) Blood sample

Before scarifying the treated rats, about $30 \mu l$ of blood was collected from eye (veins orbital plexus), for each rat per treatment, in one sterile EDTA vacationer's tube and directly sent for analyses.

\section{(B) Tissue sample}

The rats were slaughtered and the dissected. The intestines were taken (all intestine), washed by saline solution then after placed in phosphate buffer saline (pbs). The intestines were collected for each group in sterile Falcon tube.

\section{RNA extraction (for blood and tissue)}

RNA was purified from anticoagulated peripheral blood and animal tissue samples using Easy-RED Total RNA Extraction Kit.

\section{Total RNA isolation from blood sample}

A volume of $250 \mu \mathrm{l}$ of sample was prepared in 1.5 $\mathrm{ml}$ microcentrifuge tube and $750 \mu \mathrm{l}$ of easy-REDTM solution was added. The samples were mixed in room temperature for $15 \mathrm{sec}$ by vigorously vortex and the tube was incubated at room temperature $\left(15 \sim 30^{\circ} \mathrm{C}\right)$ for $5 \mathrm{~min}$. After then, $200 \mu \mathrm{l}$ of Chloroform was added and the sample was mixed in room temperature for 15 sec by vigorously vortex. Then the tube was incubated at room temperature for $5 \mathrm{~min}$. After centrifuged the tube at $13,000 \mathrm{rpm}$ at $\left(4^{\circ} \mathrm{C}\right)$ for $15 \mathrm{~min}, 400 \mu \mathrm{l}$ of the upper fluid was transferred to a new $1.5 \mathrm{ml}$ centrifuge tube. $(400 \mu l)$ of isopropanol (2-propanol) was added and mixed it well by inverting the tube $4 \sim 5$ times. The tube was incubated for $10 \mathrm{~min}$ at room temperature. After centrifuged the tube at $13,000 \mathrm{rpm}\left(4^{\circ} \mathrm{C}\right)$ for 10 min, supernatant was removed without disturbing the pellet. $70 \%$ ethanol was added and mixed the solution well by inverting the tube $4 \sim 5$ times. The mixture was centrifuged for $5 \mathrm{~min}$ at $13,000 \mathrm{rpm}\left(4^{\circ} \mathrm{C}\right)$. The supernatant was discarded without disturbing the pellet. The pellet retained the RNA was dried and kept at $-80 \mathrm{oC}$ till use. After then, RNA was dissolved by using 20$50 \mu l$ of RNase free water.

\section{Total RNA isolation from tissue sample}

\section{(A)Homogenization}

Tissue samples $(100 \mathrm{mg})$ were taken in Falcon tubes $7.5 \mathrm{ml}$ of $0.9 \%$ saline was added. Homogenization of the sample was done by vortexing.

\section{(B) Phase separation}

A volume of $250 \mu \mathrm{l}$ from homogenized tissue was prepared in $1.5 \mathrm{ml}$ micro-centrifuge tube and $750 \mu 1$ of easy-REDTM Solution was added. The sample was mixed for $15 \mathrm{sec}$ vigorously vortex and the tube was incubated at room temperature for $5 \mathrm{~min}$. after then, $200 \mu \mathrm{l}$ of chloroform was added and the sample was mixed vigorously for $15 \mathrm{sec}$. Then, the tube was incubated at room temperature for $5 \mathrm{~min}$. After centrifugation of the tube at $13000 \mathrm{rpm}\left(4^{\circ} \mathrm{C}\right)$ for 15 min, $400 \mu \mathrm{l}$ of the supernatant was transferred to a new $1.5 \mathrm{ml}$ centrifuge tube. $(400 \mu \mathrm{l})$ of isopropanol (2propanol) was added and mixed well by inverting the tube 4 5 times. The tube was incubated for $10 \mathrm{~min}$ at room temperature. After centrifuged the tube at 13,000 rpm $\left(4^{\circ} \mathrm{C}\right)$ for $10 \mathrm{~min}$, carefully the supernatant was removed without disturbing the pellet. $70 \%$ ethanol was added and the solution was mixed well by inverting the tube $4 \sim 5$ times. The mixture was centr- 
ifuged for $5 \mathrm{~min}$ at $13000 \mathrm{rpm}\left(4^{\circ} \mathrm{C}\right)$. The pellet retained the RNA was dried and kept at $-80^{\circ} \mathrm{C}$ till use. After then, RNA was dissolved by using $20-50 \mu$ l of RNase free water.

\section{Reverse transcription}

The reverse transcription reaction was performed by High Capacity cDNA Reverse Transcription Kits, that transcription Kits contain all the reagents needed for reverse transcription (RT) of total RNA to single stranded cDNA using a reaction size of $20 \mu \mathrm{L}$.

\section{The cDNA Reverse Transcription Reactions}

Volume of $10 \mu \mathrm{L}$ of $2 \times \mathrm{RT}$ master mix was pipetted into each well. $10 \mu \mathrm{L}$ of RNA sample was pipetted into each well, pipetting up and down two times to mix. The wells were centrifuged to spin down the contents and to eliminate any air bubbles. The wells were placed on ice until the thermal cycler was ready.

\section{Real time PCR amplification}

The cDNA was amplified with Thermo Scientific Maxima SYBR Green/ROX qPCR Master Mix (2X), in which The fluorescent dye in the master mix intercalates' into the amplification product during the PCR process and enables the rapid analysis of target DNA. The Master Mix contains all reagents required for qPCR (except template and primer) in a premixed $2 x$ concentrated ready-to-use solution. Primer design for qPCR is one of the most important factors to obtain efficient amplification and the primers design has been known through (Naresh et al., 2015). (Table 1).

\section{PCR conditions}

An initial denaturation step at $95^{\circ} \mathrm{C}$ for 15 min was performed. Then 50 cycles of denaturation $95^{\circ} \mathrm{C}(30 \mathrm{~s})$, annealing: $55^{\circ} \mathrm{C}$ (30s) and elongation: $72^{\circ} \mathrm{C}$ (30s). Reading was taken at annealing: $55^{\circ} \mathrm{C}$ followed by one cycle for dissociation curve at $95^{\circ} \mathrm{C}$ for $1 \mathrm{~min}, 55^{\circ} \mathrm{C}$ for $30 \mathrm{sec}$ and $95^{\circ} \mathrm{C}$ for $30 \mathrm{sec}$.

\section{RESULTS}

\section{Expression of GLP-1 and GIP hormone in blood}

GLP-1 and GIP genes expression in blood samples were detected which reveals the positive effect of both SCFAs used in this trial. GLP-1 expression was slightly increased compared to control blood sample. Increasing the dose of SCFAs displayed an increase in gene expression and recorded higher expression of 0.61more than the control sample. (Figure 1, A). However, for level GIP gene expression in blood, highly up regulation was recorded in compared to control sample and recorded two times higher the control (2.29/ GIP/GAPDH as arbitrary units). Meanwhile, increase concentration dose of SCFAs (propionic acid, 50 $\mathrm{mmol} / \mathrm{l}$ and butyric acid, $30 \mathrm{mmol} / \mathrm{l}$ ) enhance and up regulate the expression by 2.8 times higher than control and more pronounced to the first concentration used (propionic acid, $35 \mathrm{mmol} / \mathrm{l}$ and butyric acid, 20 $\mathrm{mmol} / \mathrm{l}$ ). Also, we investigated the effects of glimepiride on GIP-R and GLP-1R mRNA in the blood samples. Similar results were obtained when glimepiride was used (Group 4 and 5). Meanwhile, higher dose of glimepiride showed an inhibitory effect for GLP-1 gene expression in blood serum (Figure 1, A). Nevertheless, GIP expression reported adverse effect, contrary to GLP-1, and recorded high expression level. GIP-gene expression was up regulated by 2.46 and 2.7 (GIP/GAPDH as arbitrary units) times more than control sample for Group 4 and 5.

\section{Expression of GLP-1 and GIP hormone in Tissue}

Intestinal tissue of the treated rats showed GLP-1 and GIP genes expression in which relative increase of GLP-1 mRNA level was recorded (Figure 1 B). GIP expression level was also upregulated with low dose of SCFAs (Group 2) and dropped down with higher concentration (Group 3).

Treatment with glimepiride, which belongs to the class of drugs known as sulfonylureas, recorded downregulation of GLP-1 mRNA level (Fig. 1B). Increasing the dose lead to more inhibitory effect and GLP-1 level was decreased. In parallel, GIP level expressed was highly affected by glimepiride doses used and recorded lower level of expression. More inhibitory effect on gene expression was recoded with higher dose $(0.150$ mg of glimepiride).

Real time polymerase chain reaction depends up on the exponential amplification of a specific DNA fragment, used as a template to make millions of copies. There are different between Real time PCR and conventional PCR because it allows the continuous monitoring of the DNA produced in each cycle by using fluorophore dyes. Fluorescence is released every time after that a new DNA copy is synthesized, the quantity of DNA produced depend up on the amount of fluorescence Furthermore, real time PCR systems provide higher sensitivity and robustness, with the additional possibility to quantify the initial amount of target DNA present in a sample. The results of Real time PCR are visualized in an amplification plot ( $\mathrm{S} 1$, plateau).

The number of PCR cycles is plotted in the $\mathrm{X}$ axis, while fluorescence is represented on the $\mathrm{Y}$ axis. The amplification curve consists of three phases, the first one called an initial phase where the produced fluorescence is below the detection level of the thermo cycler, a second phase in which the fluorescence increases (being this increment exponential at the beginning of the phase), and a third phase where the reaction ends and the fluorescence is stabilized. Within the second phase, it is possible to set a threshold value, which indicates the area of exponential increase.

Threshold Cycle (CT) is the intersection point between the amplification curve and the threshold line. At this point we can find the cycle in which the fluorescence reaches the threshold value. The higher the initial DNA amount, the lesser number of cycles are needed (low Ct values) to reach the threshold the initial DNA amount, the lesser number of cycles are needed (low $\mathrm{Ct}$ values) to reach the threshold (Table 2). According to the results from real time PCR we get the value of CT for all groups for of blood and tissue samples.. 
Table (1): .List of the Target gene primer names and their nucleotide sequences.

\begin{tabular}{lll}
\hline \hline Target gene & \multicolumn{1}{c}{ Forward } & \multicolumn{1}{c}{ Reverse } \\
\hline glucagon-like peptide-1 & 5' -AATCTTGCCACCAGGGACTT-3' & 5'-AGTGACTGGCACGAGATGTT-3' \\
glucose-dependent insulin tropic & 5' - ACAAAGAGGCACAGGAGAGC-3' & 5' -AGCCAAGCAAGCTAAGGTCA-3' \\
Reference primer & 5' -ACTCCCACTCTTCCACCTTCG-3' & $5^{\prime}$-CACCCTGTTGCTGTAGCCGTA-3' \\
\hline \hline
\end{tabular}

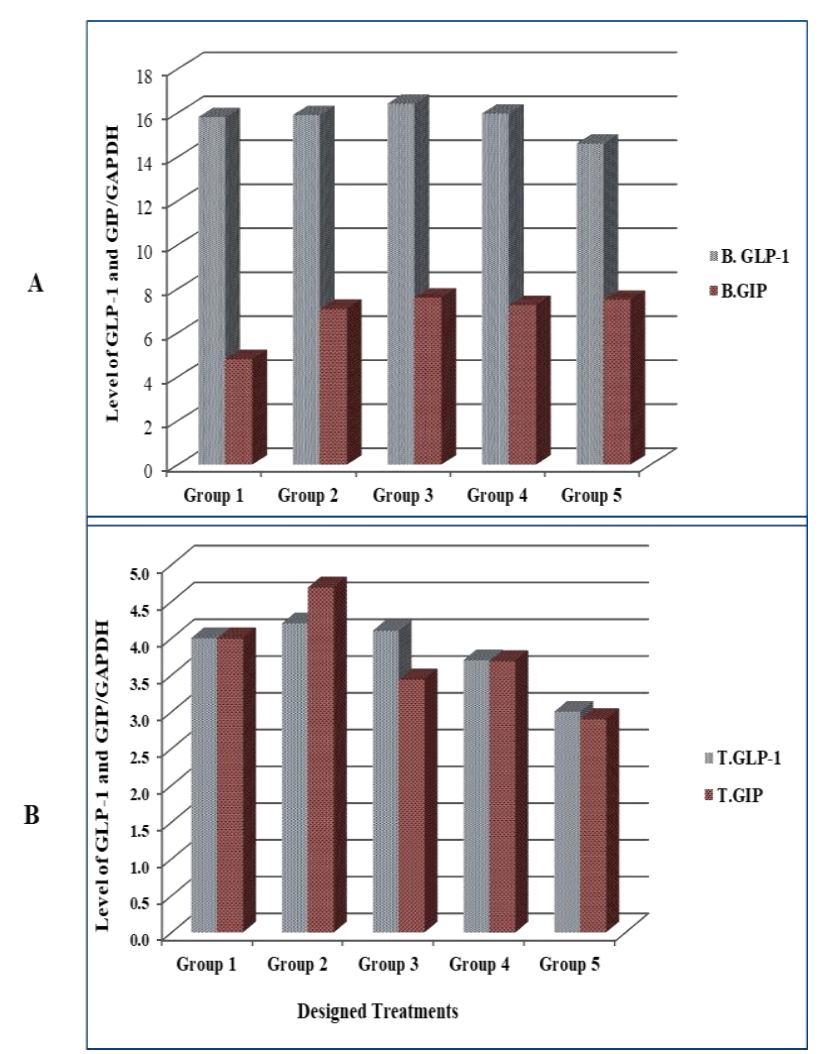

Figure 1: GLP-1 and GIP- mRNA expression levels in blood serum (A) and intestine tissue (B) resulted from different doses of SCFAs and glimepiride.

\section{Dissociation curve for (GIP) and (GLP-1) genes}

According to the results from real time PCR, we get the dissociation curve for (GIP) and (GLP-1) genes in the blood samples Dissociation curve, performed by continuous reading of the fluorescence while gradually increasing the temperature until complete DNA denaturation is (IAC) peak since its amplification product is longer achieved as a result, the dissociation plot will contain as many peaks as different DNA fragments are produced during the PCR. This process also allows the analysis of the Tm (melting temperature) of each of the originated DNA fragments, which is greater for the target gene than for the internal amplification control (Figure S2).

Reference Tm values for the IAC and the target gene should be determined in the non-template control (NTC) and positive control reactions, respectively. Dissociation curves the relationship between temperature and fluorescence.
Table (2): The $\Delta \mathrm{CT}$ for tissue and blood samples for all groups in case of GLP-1.and GIP.

\begin{tabular}{lccll}
\hline \hline Treatment & T.GLP-1 & T.GLP-1 & B.GLP & B.GIP \\
\hline Group 1 & 4 & 4 & 15.8 & 4.8 \\
Group 2 & 4.2 & 4.69 & 15.89 & 7.09 \\
Group 3 & 4.1 & 3.44 & 16.41 & 7.6 \\
Group 4 & 3.7 & 3.69 & 15.69 & 7.26 \\
Group 5 & 3 & 2.9 & 14.59 & 7.5 \\
\hline
\end{tabular}

From the tables and figures we noted that there are up regulation for the mRNA expression (GLP-1) and (GLP) for all groups in blood samples under effect of different doses of Propionic acid, Butyric acid and Glimepiride.
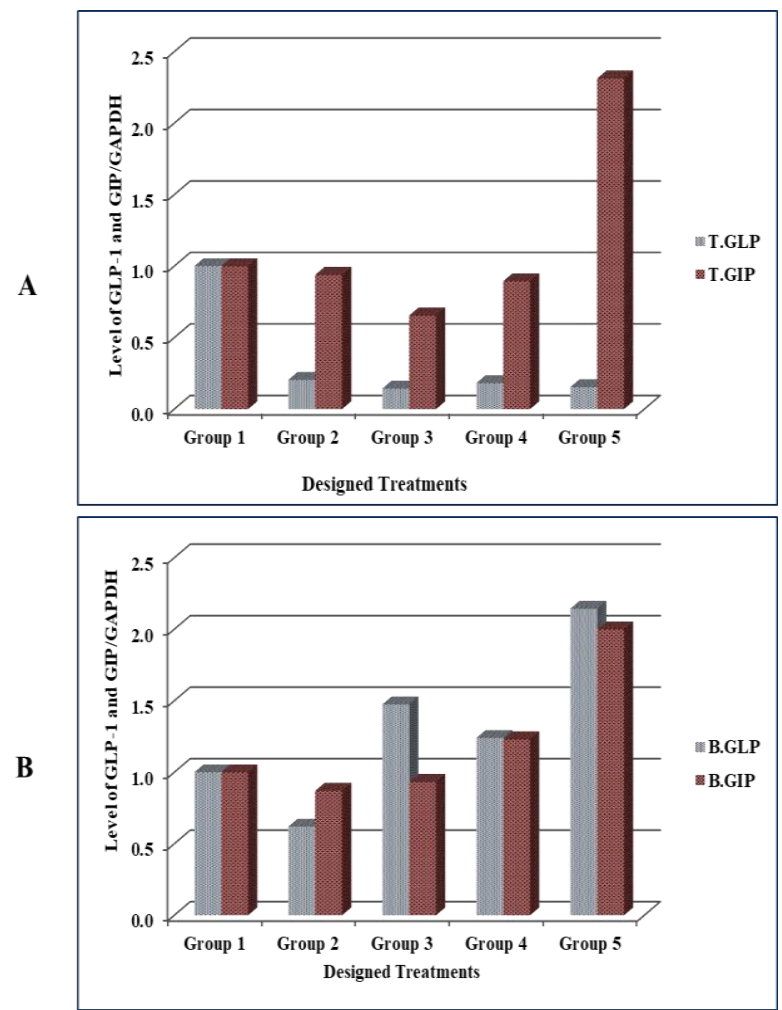

Figure 2: The fold change as related to control in case of GLP-1 and GIP. A, GLP-1and GIP in blood samples; B, GLP-1 and GIP in the intestinal tissue.

\section{DISCUSSION}

Diabetes mellitus is becoming the fast growing epidemic all over the world. In Egypt, diabetes mellitus 
is a major emerging clinical and public health problem (Hegazi et al., 2015). Diabetes type 2 management guidelines include dietary and exercise modifications and medications such as metformin sulphonyl urea insulin, Sodium-glucose cotranspor-ter type 2 (SGLT2) inhibitors (Paresh et al., 2017). Both of GIP and GLP-1 together are responsible for the incretion effect in healthy sub-jects, it is possible to analyze the incretion defect in patients with type 2 diabetes. Theoretically, the defect could be due to impaired secretion or accelerated metabolism of the incretion hormones; alternatively, the effect of the hormones could be compromised. There are many publications on the secretion of GIP in type 2 diabetes, and both increased, normal, and decreased secretion have been reported (Krarup, 1988) Incretions hormones became an important therapeutic target for treatment of diabetes type 2 by developing DPP-4 resistant GLP-1 analogue and by inhibiting the degrading enzyme DPP-4 (AyseNur et al., 2015) . These drugs are considered to be a medication option in diabetes management according to the 2016 American Diabetes Association. Both are well tolerated option that improves glycemic control with a low incidence of hypoglycemia and weight gain (Zappas et al., 2017). Incretions hormones affect glucose homeostasis through several mechanisms; decrease in appetite, reduction of body weight, improvement in insulin secretion and delay in gastric emptying (Prashant et al., 2014) .This study was designed to investigate the effects of SCFAs (butyrate and propionate) on expression of GIP and GLP-1 in experimental animals aiming to explore another way for taking benefits of both SCFAs and incretions. The results of the present study showed that the expression of GIP and GLP-1 in blood and tissues were up regulated by butyrate and propionate indicating the positive effects of these SCFAs. As regard to tissues, the expression of GIP was markedly increased more than GLP-1, this may be attributed to the presence of $\mathrm{k}$ cells in both proximal duodenal mucosa and throughout the entire intestinal mucosa ( Mortensen et al., 2003), while L-cells which synthesize GLP-1 is present in the distal intestinal mucosa (Mojsov et al., 1986 )'As for blood, the expression of GIP and GLP-1 was upregulated by butyrate and propionate, the effects on expression of both GIP and GLP-1 were nearly the same. So, the results of the present study confirm the previous findings of (Yadav et al., 2013). Also (Freeland et al., 2010), reported that rectal but not intravenous infusion of SCFAs was effective in up regulation of GLP-1 expression .The effect of SCFAs on expression of incretions is mediated by FFAR2 and FFAR3 (Herr et al., 2012). (Tolhurst et al., 2012) found that butyrate have a slower potency than acetate and propionate in stimulating GLP-1 secretion. However, acetate was not used in this study because it induces ulcers in GIT mucosa (Aguilar et al., 1999). Also the study showed that the expression of the Incretions hormone was up regulated in control group and this is due to the food provided to the rats. Since the food contains of fibre such as corn, beans and others material. These fibres were fermented by intestinal bacteria releasing the short chain fatty acids. Thus, the intestinal cells absorbed these acids and incretions unregulated. Dietary fibres have raised much interest, as they exert beneficial effects on body weight, food intake, glucose homeostasis, and insulin sensitivity this due to Short chain fatty acids (SCFAs), the end products of fermentation of dietary fibres by the anaerobic intestinal micro biota, have been shown to exert multiple beneficial effects on mammalian energy metabolism (Gijs et al., 2013). Several studies revealed the hypoglycaemic effects of SCFAs via multiple mechanisms including decr-eased expression of glycogenic enzymes glucose phosphatase and phosphoeno-lpyruvate carboxyl kinase (Sakakibara et al., 2006), increasing gut hormones PYY (satiety hormone) and by increasing glucose handling by muscle and adipose tissues (Boey et al., 2006). So, this study extends the hypoglycaemic effects of SCFAs by another mec-hanism through up regulation of incretions expression providing a special attention for the benefits of SCFAs on glucose homeostasis.

Sulphonylurea is still being as the second line recommended choice of oral glucose-lowering treatment after metformin (Kharbanda et al., 2013). It can be also used either alone or in combination with another diabetes medication (NICE clinical guideline 66, 2008). Glimepiride is one of the third generations of sulphonylurea. Glimepiride have a number of advantages over other members of sulphonylurea, curre-ntly in the market such as lower dosages, fast onset of action and lower C-peptide level of insulin, this is because of less secretion of insulin and more pronounced extra pancreatic effects .Glimepiride has the highest activity to increase the glucose transport in all sulphonylurea drugs. Glimepiride also has blood platelet aggregation inhibiting property (Huibin et al., 2015) .The most surprising finding in this study was the up regulating effect of sulph-onylurea on expression of both GIP and GLP-1. As regard to tissues, the effects of sulphonylurea on GIP were more pronounced than on GLP-1. But, the effects on expression of both GIP and GLP-1 were the same in blood .The hypoglycemic effects of sulphonylurea is mediating by increasing insulin secretion through inhibition of $\mathrm{K}^{+}$efflux from panc-reatic $\beta$-cells via sulphonylurea receptors which may be closely linked to an ATP sensitive $\mathrm{K}^{+}$Chanel. Also, sulphonylurea 
reduces serum glucagon level. The finding of our study provides unexpected mechanism for the hypoglycemic effects sulphonylurea and its derivatives by up regulation of incretions expression. Incretions in turns have different hypoglycemic effects.

\section{CONCLUSION}

The present study revealed that both SCFAs and sulphonylurea have up regulating effects on expression of incretions leading to augmentation of their hypoglycemic effects.

\section{REFERRENCE}

AGUILAR- NASCIMENTO, FRANÇA-DAS-ILVA, OLIVEIRA AND M.H. GOMES-DA-SILVA. 1999. Enhanced Mucosal Re-Epithelialization Induced By Short Chain Fatty Acids in Experimental Colitis. Brazilian Journal of Medical And Biological Research 1999 32: 961-966 ISSN 0100-879X.

AMMAR H.O., H.A. SALAMA, M. GHORAB, A.A MAHMOUD 2006. Formulation and biolo-gical evaluation of glimepiride- cyclodextrin-polymer systems. Int J Pharm 309: 129-138.

AYSENUR TORUN AND DERUNTANERERTUGRUL. 2015. Incretin System in the Pathogenesis of Type 2 Diabetes and the Role of Incretin Based Therapies in the Management of Type 2 Diabetes. In Tech Open, Published on: 2015.

BOEY , D. , S. LIN , T. KARL , P. BALDOCK , N. LEE , R. ENRIQUEZ, M. COUZENS , K. SLACK , R. DALLMANN, A. SAINSBURY , ET AL. 2006. Peptide YY Ablation In Mice Leads to The Development of Hyperinsulinaemia And Obesity. Diabetologia. 49: 1360 - 1370.

DAVIS SN 2004. The Role of Glimepiride in the Effective Management of Type 2 Diabetes. J Diabetes Complicat 18: 367-376.

FREELAND KR, TMS. WOLEVER. 2010. Acute Effects Of Intravenous and Rectal Acetate on Glucagonlike Peptide1, Peptide YY, Ghrelin, Adiponectin and Tumour Necrosis Factora british Journal of Nutrition. 2010;103 (3): 460-466.

GIJS DEN BESTEN, VAN EUNEN KAREN, ALBERT K. GROEN, KOEN VENEMA, DIRK $\neg$ JANREIJNGOUD, AND BARBARA M. BAKK. 2013. The Role of Short Chain Fatty Acids in The Interplay Between Diet, Gut Microbiota, and Host Energy Metabolism. Received Jan 18; Revised 2013 Jun 21.

HEGAZI R, M. EL-GAMAL, N. ABDEL-HADY, O. HAMDY 2015. Epidemiology of and Risk Factors for Type 2 Diabetes in Egypt. Ann Glob Health. 2015Nov-Dec; 81 (6): 814-820.doi:10.1016/j.aogh. (2-015). 12.011.

HERR NR, J. PARK, Z.A. MCELLIGOTT, A.M. BELLE, R.M. CARELLI, R. MARK WIGHTMAN 2012. In Vivo Voltammetry Monitoring of Electrically Evoked Extracellular Norepinephrine in
Subregions of the Bed Nucleus of the Stria terminalis. Journalof Neuroph-ysiology. 2012;107 (6): 1731-1737.

HOLST J.J. 2007. The Physiology of Glucagonlike Peptide 1. Physiol Rev. Oct ; 87: 1409-1439.

HUI-BIN ZHANG, YA-AN ZHANG, GUAN-ZHONG WU B, JIN-PEI ZHOU, WEN-LONG HUANG , XIAO-WEN HU. 2008. Synthesis And Biological Evaluation of Sulfonylurea And Thiourea Derivatives Substituted With Benze-nesulfonamide Groups As Potential Hypo-glycemic Agents. Received 27 July 2008 Revised 8 January 2009 Accepted 24 January 2009 Available Online 29 January 2009.

KAU AL, P.P. AHERN, N.W. GRIFFIN, A.L. GOODMAN, J.I. GORDON 2011. Human Nutrition, the Gut Microbiome and the Immune System. Nature. 2011; 474: 327-336.

KHARBANDA AND M. SARWARALAM. 2013. Evolution of Sulfonylureas in the Treatment Of Diabetes Mellitus. Department of Chemistry, Faculty of Science, Jamiahamdard, New Delhi-110062 Received 14 June 2013; Accepted 15July 2013.

KRARUP T. 1988. Immunoreactive gastric inhibitory polypeptide. Endocr Rev 9: 122-134.

LINDGREN O., R.D. CARR, C.F. DEACON, J.J. HOLST, G. PACINI, A. MARI 2011. Incretin Hormone and Insulin Responses to Oral Versus Intravenous Lipid Administration In Humans. J Clinendocrinolmetab. Aug 2011; 96: 2519-2524.

MRILLER G., D. HARTZ, J. PRINTER, R. OKONOMOPULOS, W. KRAMER 1994. Differential Interaction of Glimepiride And Glibenclamide With The Beta-Cell Sulfonylurea Receptor. I Binding Characteristics. 1994 May 11; 1191 (2): 267-277.

MOJSOV S., G. HEINRICH, I.B. WILSON, M. RAVAZZOLA, L. ORCI, AND J.F. HABENER 1986. Preproglucagon Gene Expression In Pancreas And Intestine Diversifies At The Level of PostTranslational Processing. J Biol Chem. 1986; 261: 11880-11889.

MORTENSEN K, L.L. CHRISTENSEN, J.J. HOLST, AND C. ORSKOV 2003. GLP-1 And GIP Ar Colocalized in A Subset Of Endocrine Cells In The Small Intestine. Regulpept. 2003, 114: 189-196.

NARESH RAMESH, SIMAMORTAZAVI, SURAJUNNIAPPAN 2015. Nesfatin-1 Stimulates GlucagonLike Peptide-1 And Glucose-Dependent Insulinotropic Polypeptide Secretion From STC-1 Cells In Vitro. Biochemical And Biophysical Research Communications. Http://Dx.Doi.Org/10.1016/J.Bbrc.2015.04.100.

PARESH DANDONA AND AJAY CHAUDHURI 2017. Sodium-Glucose Co-Transporter 2 Inhibitors for Type 2 Diabetes Mellitus: An Overview for the Primary Care Physician. Int J Clinpract. May; 71 (5): E12937.

PERLEY M.J., D.M. KIPNIS 1967. Plasma insulin 
responses to oral and intravenous glucose: studies in normal and diabetic sujbjects. J Clin Invest. Dec 1967;46: 1954-1962.

PRASHANT, G. OLEG AND G. HOLZ GEORGE 2014. Regulation of Glucose Homeostasis By GLP-1. Progmolbioltransl Sci. Author Manuscript; Available in PMC 2014 Sep 10. Published In Final Edited Form As: Progmolbioltransl Sci. 2014; 121: 23-65. Doi: 10.1016/B978-0-12-800101-1.00002-8.

SAKAKIBARA, S., T. YAMAUCHI, Y. OSHIMA, Y. TSUKAMOTO, AND T. KADO-WAKI. 2006. Acetic acid activates hepatic AMPK and reduces hyperglycemia in diabetic KK-A(y) mice. Biochem. Biophys. Res. Commun. 344: 597 - 604.
TOLHURST G, HEFFRON H, LAM YS 2012. Short chain Fatty Acids Stimulate Glucagonlike Peptide1 Secretion Via the Gproteincoupled Receptor FFAR2. Diabetes 2012; 61 (2): 364-371.

YADAV H, J.H. LEE, J. LLOYD, P. WALTER, S. G. RANE 2013. Beneficial Metabolic Effects of A Probiotic Via Butyrateinduced GLP1hormone Secretion. The Journal of Biological Chemistry. 2013; 288 (35): 25088-25097.

ZAPPAS, MEREDITH GENTES AND BENITA WALTON-MOSS. 2017. Use of Incretin Therapy In The Treatment Of Type 2 Diabetes Mellitus.June 2017 Volumes 13, Issue 6.Pages 418-424. 


\title{
تأثير مشتقات السلفونيل يوريا والأحماض الدهنية قصيرة السلسلة على تكوين هرمون الانكراتنز في خلايا الحيوانات الحية
}

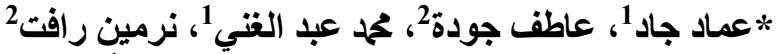

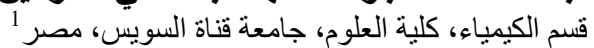 \\ قسم الكيمياء الحيوية والبيولوجيا الجزيئية الطبية، كلية الطب، جامعة الطبة الزقازيق، مصر 2 \\ الملخص العربــــي
}

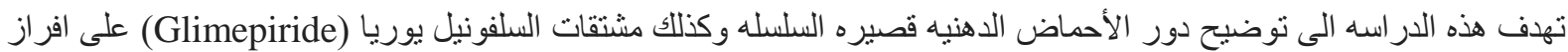

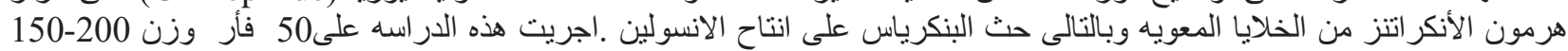

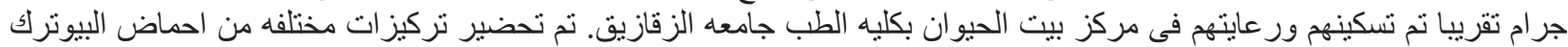

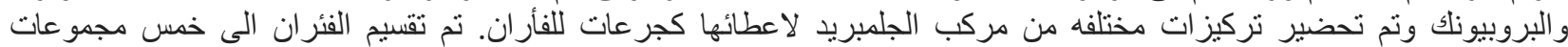

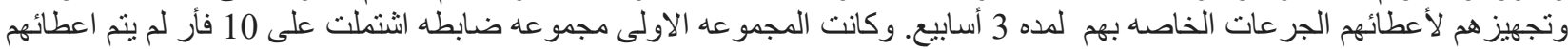

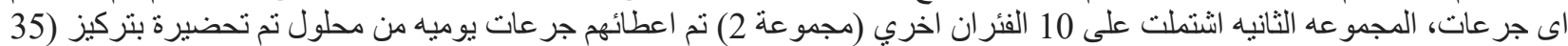

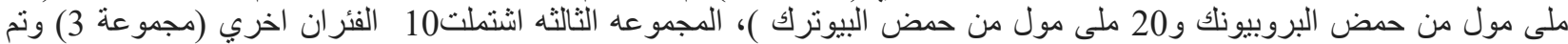

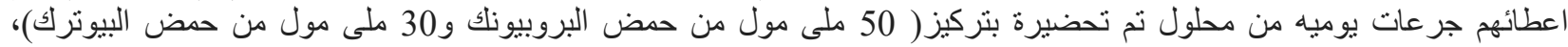

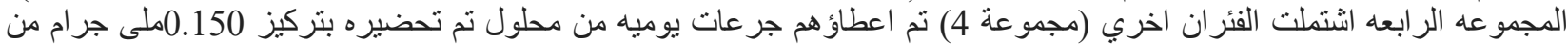

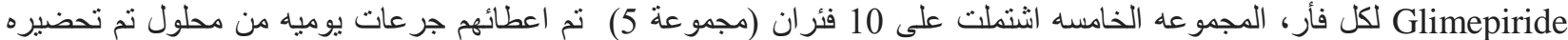

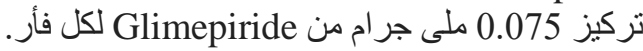

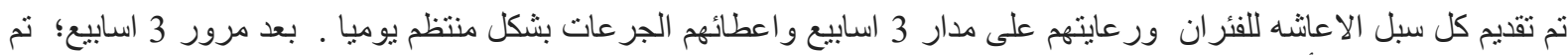

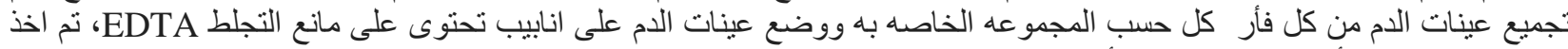

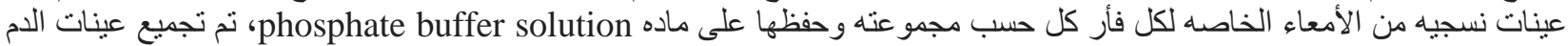

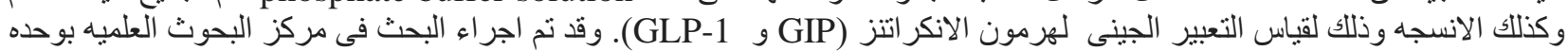

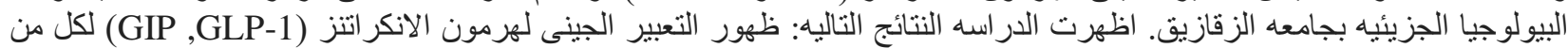

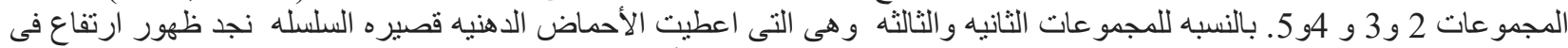

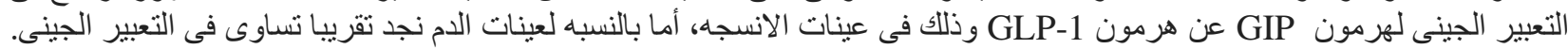

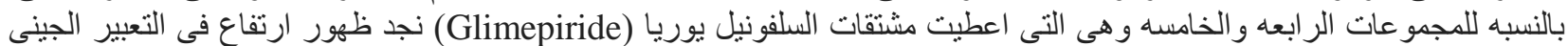

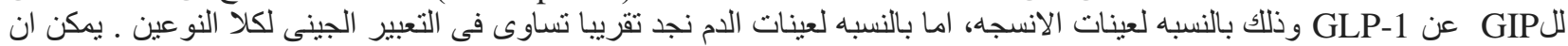

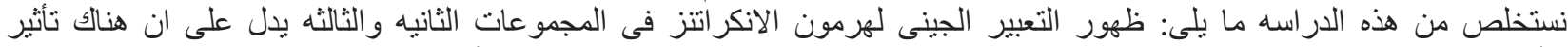

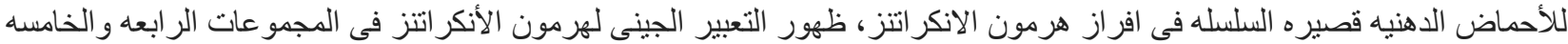

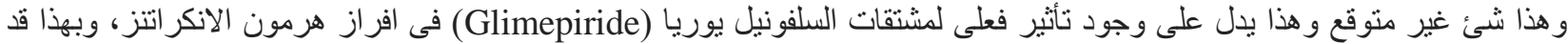

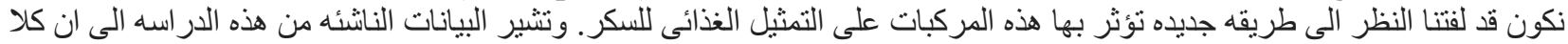

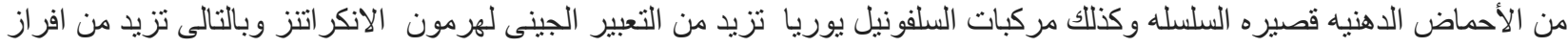

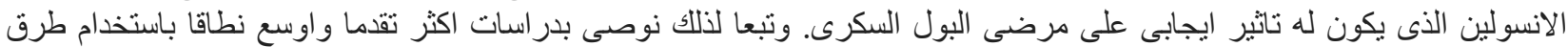
ومنهجيات مختلفه للتعرف على علاجات جديده لمرضى النى السكرى. 